\title{
Interest Rates and Their Prospect in the Recovery
}

MUCH CONCERN has been expressed in the financial press and by other observers about the prospects for interest rates in 1975. The particular fear is that the sharp declines in short-term interest rates in 1974 will be followed by sharp increases in both short- and long-term rates in 1975 under the pressure of the massive federal deficits expected in 1975 and 1976.

This paper addresses two questions: First, has the movement in shortand long-term interest rates since mid-1974 been unusual in light of the slow growth of money and the collapse in economic activity? Second, will the large volume of deficit financing, induced in part by the tax cuts, lend a strong upward push on interest rates in 1975? These can be two aspects of the same question, because an unexpected and fundamental shift in the relationships among interest rates, income, and money may cloud the implications of the deficit for interest rates.

\section{The Recent Behavior of Interest Rates and Money Demand}

As figure 1 demonstrates, short-term rates peaked in the summer of 1974, and have since fallen steeply until quite recently. Long-term rates have also

Note: The views expressed in this paper are my own and do not necessarily agree with those of the Board of Governors. I want to thank members of the Brookings panel for their many constructive comments on an earlier version of this paper. 
Figure 1. Selected Interest Rates, Monthly Averages,

\section{January 1974-March 1975}

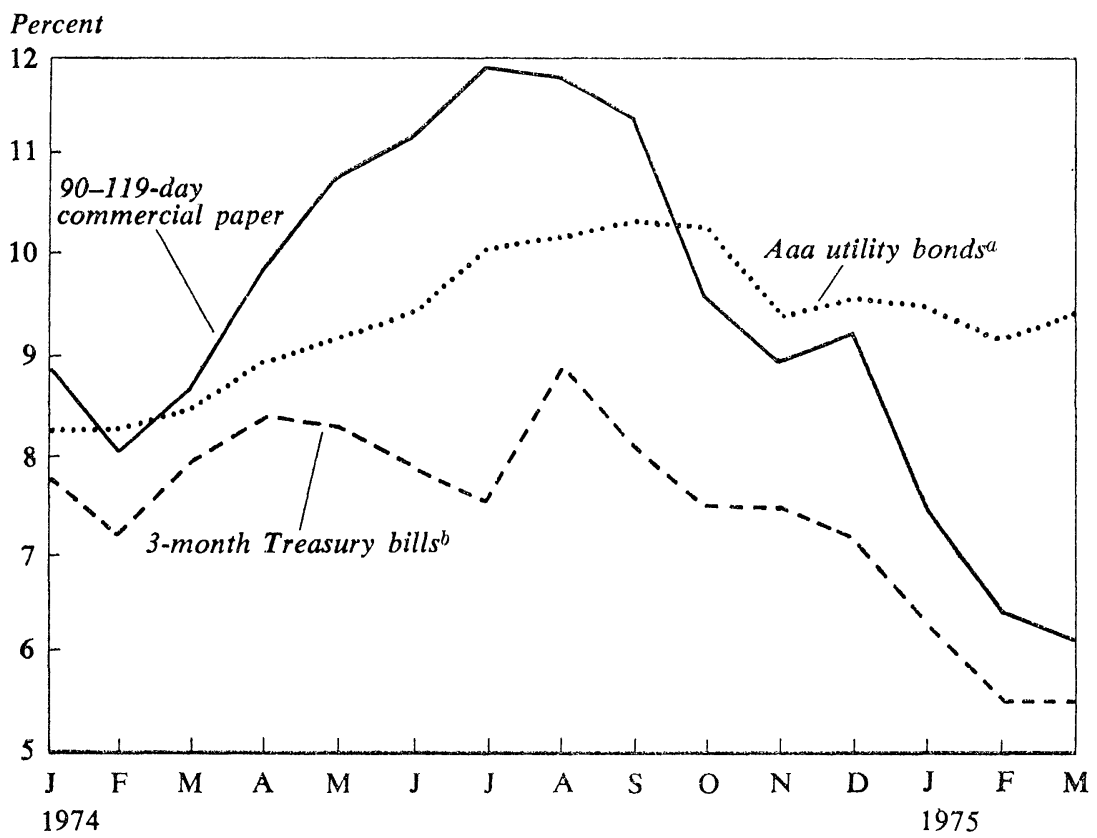

Sources: Federal Reserve Bulletin, vol. 61 (April 1975), pp. A 27, A 28; and two preceding issues. a. Recently offered series.

b. Market yield.

fallen from their peaks, but much more gradually; since November they have moved without a clear trend. These movements were accompanied by an appreciable slowing in the growth of nominal income during 1974, which, however, remained positive until the first quarter of 1975. Real income fell throughout 1974, moving into a severe decline in the last quarter of 1974 and the first quarter of 1975 . While the money stock $\left(M_{1}\right)$ grew fairly rapidly in the first half of 1974, after June its growth first slowed and then behaved erratically; on balance, it averaged only 1.4 percent (annual rate) from June through January, before speeding up during February and March.

In light of these patterns, was the large decline in short-term interest rates and the much smaller decline in long-term rates to be expected? Was the erratic pattern of growth in $M_{1}$ predictable? The answer to the first question is a qualified "yes" and to the second question a qualified "no."

These answers arise from an examination of the residuals from regression 
equations in the SMP (Social Science Research Council-M.I.T.-University of Pennsylvania) model that describe the behavior of money demand and interest rates. If these equations exhibit no unusual behavior in their prediction errors, one would infer that the behavior of money and interest rates during the recession was to be expected. If, on the other hand, the prediction errors are unusually large, one would conclude that recent financial developments were unexpected.

The single-period prediction errors from the money-demand (currency plus demand deposit) equations in the SMP model for 1973 and 1974 are shown in figure 2. The equations used to form the predictions of $M_{1}$ were as follows:

$$
\ln M C=0.22 \ln P C E-0.005 \ln R T B+0.88 \ln M C_{-1}
$$

Standard error $=0.003$; sample period: 1955:4-1971:4.

$$
\begin{aligned}
\ln \frac{M D}{Y}=0.28 \ln \frac{M D_{-1}}{Y}- & 0.06 \ln R T B-0.12 \ln R S D \\
& +0.08 \ln \frac{R D I S}{R D I S_{-1}}-0.34 \ln \frac{y}{N}-0.05,
\end{aligned}
$$

Standard error $=0.0068$; sample period: 1955:2-1972:4.

where

$$
\begin{aligned}
M C & =\text { currency held by the nonbank public } \\
P C E & =\text { personal consumption expenditures } \\
R T B & =\text { interest rate on Treasury bills } \\
M D & =\text { demand deposits held by the nonbank public } \\
Y & =\text { GNP } \\
R S D & =\text { interest rate on savings deposits } \\
R D I S & =\text { discount rate } \\
y / N & =\text { GNP per capita in } 1958 \text { dollars. }
\end{aligned}
$$

Actual values of the exogenous variables in these equations-real and nominal GNP and short-term interest rates-were used to form the predictions. As figure 2 clearly reveals, the equations seriously overstated $M_{1}$ growth in the second half of $1974 .{ }^{1}$ What is more, the errors were several times greater than those obtained in earlier periods. ${ }^{2}$

1. All the equation predictions in this paper are single-period predictions that have set the rho term equal to zero. As a result, the equations exhibit serially correlated errors. When actual predictions are made, there is less concern in distinguishing the role of structural variables from information on the error structure and an estimated value of rho is used.

2. As will be shown below, the prediction of the demand for demand deposits was responsible for the large errors; the currency predictions were quite accurate. 
Figure 2. Actual and Predicted $M_{1}$, Quarterly, 1973 and 1974

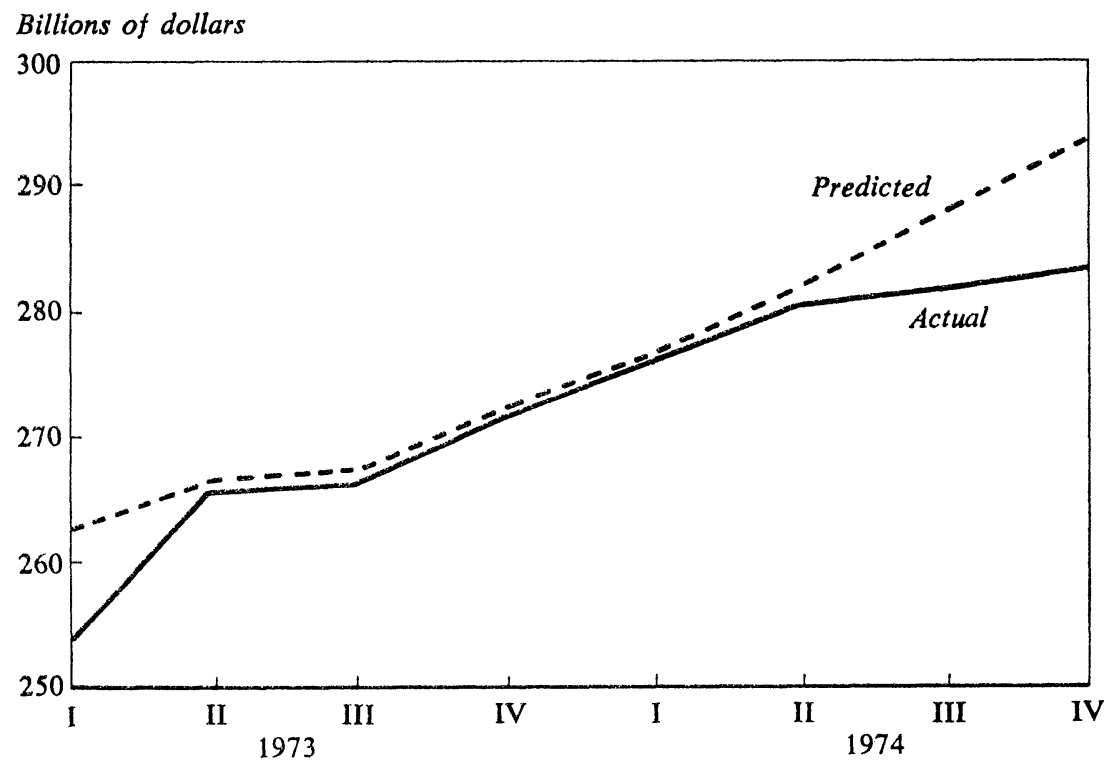

Sources: Actual-SMP data bank; predicted-SMP model, using money-demand equations (1) and (2) given in the text. $M_{1}=$ currency plus demand deposits.

The errors in the money-demand relationships give some idea of whether the decline in interest rates in 1974 was smaller than would have been expected on the basis of past relationships. The equations imply that-given the actual values of other exogenous variables-Treasury bill rates of 8.8 percent and 8.3 percent in the third and fourth quarters would have produced a 6 percent increase in $\mathrm{M}_{1}$ at an annual rate. Actual bill rates in the two quarters were 8.2 and 7.4 percent, respectively, which should have yielded a greater money demand; yet actual $\mathrm{M}_{1}$ growth was only 2.0 and 2.2 percent in those quarters. ${ }^{3}$ Thus, according to the money-demand equations, actual bill rates were sufficiently low to produce an $\mathbf{M}_{1}$ growth in excess of 6 percent.

Treating the errors in the equations as reductions in the intercept of the money-demand equations - that is, treating them as if the money-demand equation "shifted" downward-makes it possible to calculate the interest

3. The quarterly $M_{1}$ figures used in the equations are averages of the two months surrounding the end of the quarter; for example, the figure for the fourth quarter is the average of December and January. 
rates required to achieve a 6 percent $M_{1}$ growth. To do this, the intercepts of the currency and demand-deposit equations in the third and fourth quarters were adjusted by each equation's error in each quarter. With the adjusted equations, the Treasury bill rates required to obtain 6 percent $M_{1}$ growth in the third and fourth quarters were 6.2 percent and 4.1 percent, respectively.

The large errors in predicting money demand are sufficient but not necessary to explain the slow growth in $\mathrm{M}_{1}$. The demand for money provides predictions of the money stock given short-term interest rates. With the interest rates that prevailed in the third and fourth quarters, the money-demand function predicted $\mathrm{M}_{1}$ growth higher than the actual. However, money growth need not have been as slow as it was. If bank reserves had been supplied at a rate consistent with more rapid growth in $\mathrm{M}_{1}$, interest rates would have fallen sufficiently to equate money demand with the more rapidly growing supply and the money stock would have expanded more rapidly. Thus, the issue is not that the decline in interest rates was so large but rather that it was not large enough to spur more rapid expansion in $\mathbf{M}_{1}$.

Given the actual decline in short-term interest rates, the behavior of longterm rates was not surprising. The model's equation for the interest rate on newly issued corporate bonds, taken as a measure of long-term rates, is

$$
\begin{gathered}
R N I=0.76+\sum_{i=0}^{18} b_{i} R C P_{-i}+\sum_{i=0}^{18} c_{i} \frac{\Delta P C O N_{-1}}{P C O N_{-i-1}}+0.33 \sigma R C P \\
b_{0}=0.18, \sum b_{i}=0.94 ; c_{0}=4.83, \sum c_{i}=31.18 \\
\text { Standard error }=0.17 ; \text { sample period: } 1954: 4-1971: 2
\end{gathered}
$$

where

$R N I=$ interest rate on newly issued Aaa utility bonds

$R C P=$ commercial paper rate

$P C O N=$ consumption prices (percent change measured at annual rate)

$\sigma R C P=$ a measure of the standard deviation of RCP over the previous eight quarters.

The equation did overpredict the rate on new issues in late 1973 and 1974 by a substantial amount, the maximum error being 1.4 percentage points in the first quarter of 1974. But the pattern of predictions captured the upsurge in long-term rates in 1973 and 1974 and the moderate decline in late 1974. The errors made during the period appear to be explainable. In the equation a distributed lag on the percentage change in consumption prices 
serves as a proxy for the expected rate of inflation. The behavior of this price variable was not an appropriate measure of expected inflation because of the rapid rise in consumption prices relative to other prices during the period. This variable probably accounts for much of the overprediction of the long-term rate in 1973 and 1974.

\section{MONEY DEMAND}

While the declines in interest rates may not be surprisingly large, the sizable errors in predicting money demand in the second half of 1974 remain to be explained. The search for explanations is frustrating and perhaps fruitless, particularly because the errors may have resulted from large random disturbances. An effort to "explain" the errors is always an exercise in ex post theorizing, which is often difficult to distinguish from pure rationalization. If the ex post arguments appear to be compelling, it is crucial to test the role of these factors not only in the current situation but also at other times when they appear to operate.

A separate look at the model's equations for currency and demand deposits, the two components of $\mathrm{M}_{1}$, clearly shows that the latter is responsible for the overprediction in 1974; the very rapid currency growth during the year was predicted quite accurately. The errors in the demand-deposit equation in 1974 are several times larger than those obtained at any other time, whatever the economic conditions. The problem is to isolate any special factors at work in the second half of 1974 that could account for the extremely large errors in predicting growth in demand deposits.

Many of the possible explanations of the apparent collapse in money demand are plausible and serve to highlight some of the problems with conventional money-demand functions. ${ }^{4}$ These functions are of the form

$$
\ln \frac{M}{Y}=a_{0}-a_{1} \ln \frac{y}{N}-a_{2} \ln r+a_{3} \ln \frac{M_{-1}}{Y}
$$

where

$$
\begin{aligned}
M & =\text { money } \\
Y & =\text { nominal GNP }
\end{aligned}
$$

4. I have benefited greatly from several discussions with Jared J. Enzler on the problems of money demand. For an excellent review of the state of the art concerning money demand, see Stephen M. Goldfeld, "The Demand for Money Revisited," BPEA (3:1973), pp. 577-638. 


$$
\begin{aligned}
y & =\text { real GNP } \\
N & =\text { population } \\
r & =\text { interest rates } \\
a_{1,2,3} & =\text { coefficients greater than zero. }
\end{aligned}
$$

The negative coefficient on real per capita GNP, $y / N$, implies a less than unitary elasticity of money demand with respect to real GNP. The public economizes on money balances as real transactions (for which $y / N$ is the proxy) rise. Thus, an increase in real per capita income will raise velocity. This result accords with the microeconomic inventory approach to money demand.

A less than unitary elasticity of demand implies that a decline in real GNP per capita, with nominal GNP and interest rates unchanged, will increase the demand for money. This can be seen when equation (4) is rewritten to obtain

$$
\begin{aligned}
M=a_{0}+\left(1-a_{3}\right) \ln Y-a_{1} & \ln y \\
& +a_{1} \ln N-a_{2} \ln r+a_{3} \ln M_{-1} ;
\end{aligned}
$$

or, defining $P$ as a measure of the price level so that $Y=P y$,

$$
\begin{aligned}
M=a_{0}+\left(1-a_{3}\right) \ln P+\left(1-a_{3}\right) \ln y-a_{1} \ln y \\
\quad+a_{1} \ln N-a_{2} \ln r+a_{3} \ln M_{-1} .
\end{aligned}
$$

This rearrangement of terms makes it clear that a 1 percent rise in $P$ offset by a 1 percent decline in $y$ will leave nominal income unchanged, but will raise the demand for nominal money balances, by $a_{1}$ percent.

According to this specification, when real income is falling in a recession, the public will be less careful in its cash management, given interest rates and nominal income. In most recessions, the movement of nominal income is dominated by the movement of real income. As real income falls, so does money income, and predicted money demand falls with it, albeit to a lesser degree. In the current recession, however, nominal income continued to rise because prices rose faster than real income fell. Thus, predicted money demand rose even as real income fell.

There is strong evidence that the public has learned to use its money balances more intensively over time. Furthermore, theory suggests that the incentive and ability to economize on money are related to real transactions and to interest rates. However, the behavior of the public is probably more complicated than is implied in conventional money-demand func- 
tions. The propensity to economize on money balances probably cannot be captured by the elasticity estimate on real transactions. Once individuals and firms have economized on cash holdings, they will not unlearn all their lessons when interest rates and real transactions fall. Thus, in an important sense, money demand may not be completely "reversible." This ratchet effect should be particularly important when technological developments, which may have been stimulated by high interest rates and large volumes of transactions, are involved. Furthermore, the upward trends in interest rates and real GNP in the postwar period make it difficult to distinguish the effects of these variables on cash management from those of a time trend.

It is beyond the scope of this paper to specify a money-demand function that would distinguish among the factors that influence economizing on money balances. But the residuals from the SMP demand-deposit equation should provide some insights into the issue. If a ratchet effect or a trenddetermined increase in the technology of cash management is important, one might expect money demand to be overestimated during recessions. However, residuals from the demand-deposit equation do not show such a pattern for recessions before the present one.

As a further test, new projections were made from the demand-deposit equation, (2), using the past-peak value of real per capita GNP rather than its actual current value as a crude means of capturing a ratchet effect. ${ }^{5}$ Past-peak income was used so that the declines in real GNP would not work to raise the demand for money relative to nominal GNP. The estimates were reduced by $\$ 2.4$ billion and $\$ 4.4$ billion in the third and fourth quarters of 1974 , respectively, thus reducing by that amount the residuals of $\$ 6.1$ billion and $\$ 10.8$ billion for those quarters in the original projection. But the errors were worse for previous recessions using this new formulation. Thus, the evidence is inconclusive. Since 1974 is unique in the number of quarters in which nominal and real GNP moved in opposite directions, and the estimates were improved for 1974, the evidence does suggest the need for further work on the possible nonreversibility of money demand.

The recent strange behavior of predicted money demand might result, in part, from the use of the Treasury bill rate in the money-demand function. In principle, all market rates should be present in one form or another; but because of multicollinearity the Treasury bill rate was chosen as a proxy for

5. Since the function was not reestimated using past-peak real income but was simply rerun applying the coefficient for real per capita GNP to past-peak income, the residuals are only suggestive of the possible misspecification of the equations. 
other rates. Recently, the bill rate has followed a pattern considerably different from that for other rates. One reason might be that interest on Treasury bills is not subject to state and local income taxes, so that as interest rates rise, bill rates and other market rates increasingly diverge. The spread should be reduced when interest rates fall. This factor could be important since some large states, including New York and California, have maximum personal tax rates of 11 percent or more. A second reason may be the recent very large increase in Treasury bill holdings by foreigners. Some of this unusual demand is from foreign central banks, and some apparently from suddenly rich Arabs with such strong preferences for safety that they prefer bills in spite of the large rate differential. Still another possibility is that recent economic shocks have caused domestic portfolio managers to attach unusually large risk premiums to private debt.

In order to examine the importance of the relatively low bill rates in the demand-deposit equation, the actual bill rate was increased in 1974 sufficiently to return it to a normal relationship to the commercial paper ratewhich was probably more typical of overall short-term interest rates in 1974. The actual bill rates in 1974 were adjusted by the residuals in the model's equation for the commercial paper rate, which takes this rate as a function of the bill rate. ${ }^{6}$ These errors measure the unusual spread that has opened up between the bill and commercial paper rates. The errors for the four quarters of 1974, expressed in percentage points, were $0.1,-2.4,-2.4$, and 0.3 , respectively. When these errors are added to the bill rate and fed into the demand-deposit equation, its original errors of $\$ 6.1$ billion and $\$ 10.8$ billion were reduced by $\$ 5.1$ billion and $\$ 3.4$ billion in the third and fourth quarters, respectively.

Another explanation for the collapse in money demand may lie in changes in compensating balances that commercial banks often require of their loan customers as a condition for extending credit or lines of credit. In the latter part of 1974, commercial banks abandoned or modified their primerate formulas to keep their lending rates unusually far above market interest rates, expecting thereby to enhance their profits and to reduce the share of loans in their portfolios. Under this pressure, borrowers may have shifted

6. The equation relates the commercial paper rate to the current and one-quarterlagged values of the Treasury bill rate:

$$
R C P=0.54+0.71 R T B+0.35 R T B_{-1} .
$$

Standard error $=0.14$; sample period: 1953:2-1969:3. 
their business away from banks toward other sources of credit-such as commercial paper-and taken their compensating balances with them, thus reducing measured money demand.

Given the total lack of data on compensating balances, the importance of this phenomenon is uncertain. However, the reduction in compensating balances was probably not very large. Most firms that borrow in the commercial paper market must maintain credit lines at commercial banks and, hence, compensating balances. Furthermore, the terms on which borrowers regain access to credit at commercial banks will depend in part on the size of the balances that they have maintained. Businesses would, therefore, hesitate to reduce their deposit balances. Thus, the restrictive lending policies of commercial banks are unlikely to have produced much reduction in compensating balances.

Some argue that, because much of the public always holds minimal demand deposits or because of innovations such as NOWs, POWs, WOWs (negotiable orders of withdrawal, payment orders of withdrawal, written orders of withdrawal, respectively), and money-market mutual funds, $M_{1}$ is no longer an interesting variable. If this assertion were correct, one would expect to see a sizable shift into savings- and time-deposit liabilities of banks and nonbank thrift institutions. Such shifts must lie behind the arguments that higher orders of $M$, such as $M_{2}\left(M_{1}\right.$ plus time deposits at commercial banks other than certificates of deposit) or $M_{3}\left(M_{2}\right.$ plus deposits at nonbank thrift institutions) are more reliable variables than $\mathbf{M}_{1}$.

A shift away from $M_{1}$ to such interest-bearing deposits would show up as underpredictions in the model's equations for commercial bank savings and time deposits (other than certificates of deposit) and the sum of liabilities of savings and loan associations and mutual savings banks. However, the errors show little evidence of a persistent tendency to underestimate the growth in these deposits and no clear offset to the overprediction of money demand in the second half of 1974 . What does show up from these equations are large errors in both directions: predicting those bank and thrift accounts is not easy. ${ }^{7}$

7. Recent prediction errors do suggest that these equations have problems. The major difficulty in predicting these savings and time accounts appears to lie with obtaining interest-rate variables that adequately measure the rates paid by banks and thrift institutions. For a brief discussion of the difficulties, see my comments on William E. Gibson, "Deposit Demand, 'Hot Money,' and the Viability of Thrift Institutions," BPEA (3:1974), pp. 633-34. 
Many other factors might explain the collapse in money demand, such as the mix of GNP, the volume of financial transactions, the expected rate of inflation, the decline in real wealth, and the like. Indeed, when all the revisions are made in the GNP accounts and in the measurement of the money stock, the problem of explaining $\mathrm{M}_{1}$ in the second half of 1974 might well disappear.

While its recent behavior may be something of a mystery, the important lesson appears to be that no evidence attests to a fundamental structural shift in money demand. While one must wait for new observations to see if large errors persist, preliminary data suggest that the prediction errors for the first quarter of 1975 are much smaller. Thus, the second half of 1974 appears to have been an unpleasant episode, but conventional money-demand functions can be used as one tool for analyzing the future course of interest rates.

\section{The Prospects for Interest Rates}

Many observers have expressed the concern that the sharply increased government borrowing resulting from the large deficits in 1975 and 1976 will put substantial upward pressure on interest rates that will tend to choke off the prospective recovery. Those who find this result inevitable argue that if the Federal Reserve were to buy a substantial part of the new debt, it would only avert the rise in the short run. Eventually, such an expansionary monetary policy would, it is feared, rekindle both actual and anticipated inflation, and in so doing would cause nominal interest rates to rise even higher.

Leaving direct comment on this argument aside for the moment, a review of the historical relationship between interest rates and deficits might be useful. These two series are presented for 1952 through 1975: 1 in figure 3. It is clear that, historically, large deficits tend to be associated with recessioninduced declines in revenues and with declines in interest rates. This historical record certainly gives no evidence of a simple correlation between large deficits and high or rising interest rates.

Perhaps during the periods of deficits and declining interest rates the central bank was pumping in so much money that the debt was effectively monetized. Again, the historical record does not support this conjecture. Figure 4 shows the annualized rates of growth of $M_{1}$ quarter by quarter 


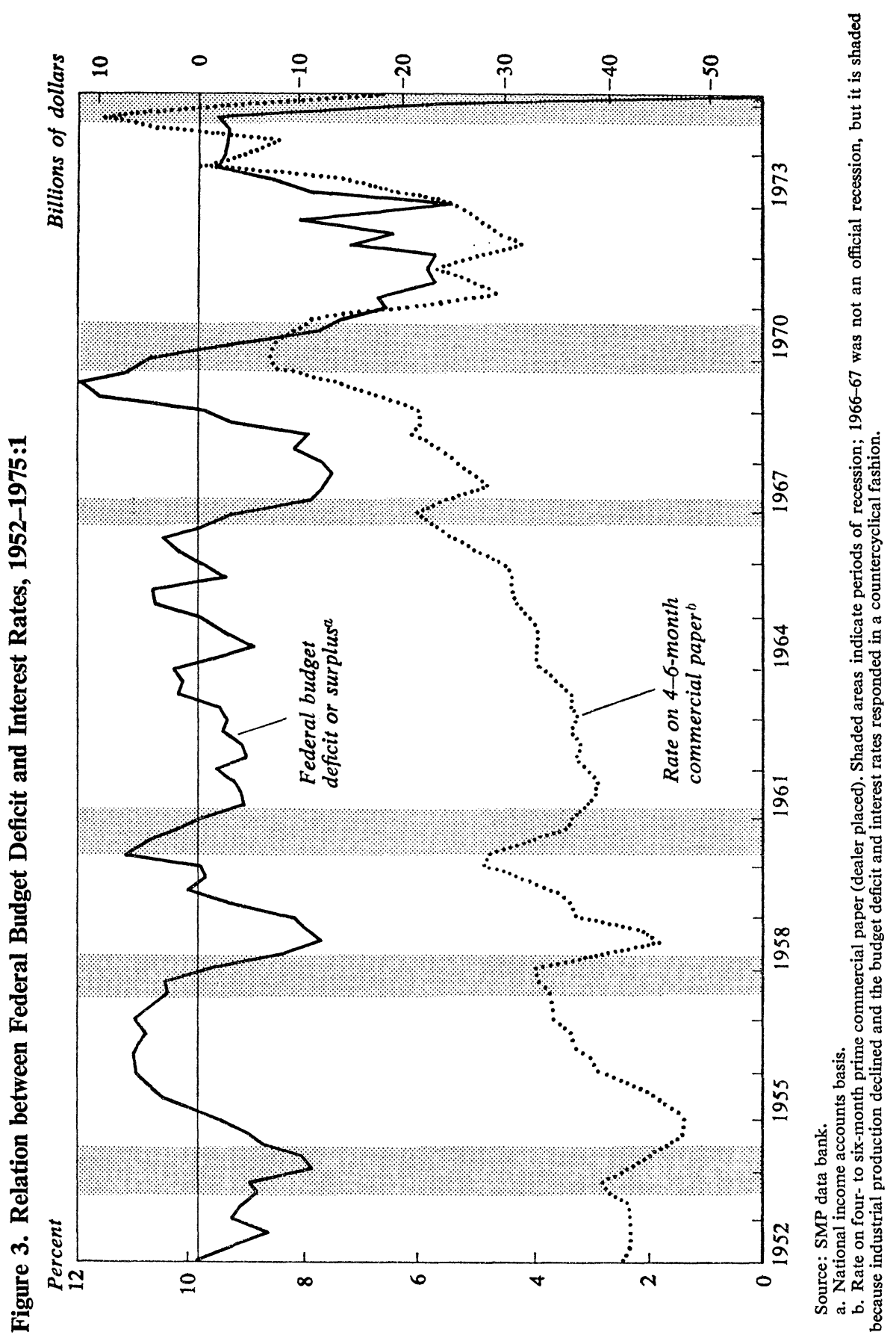




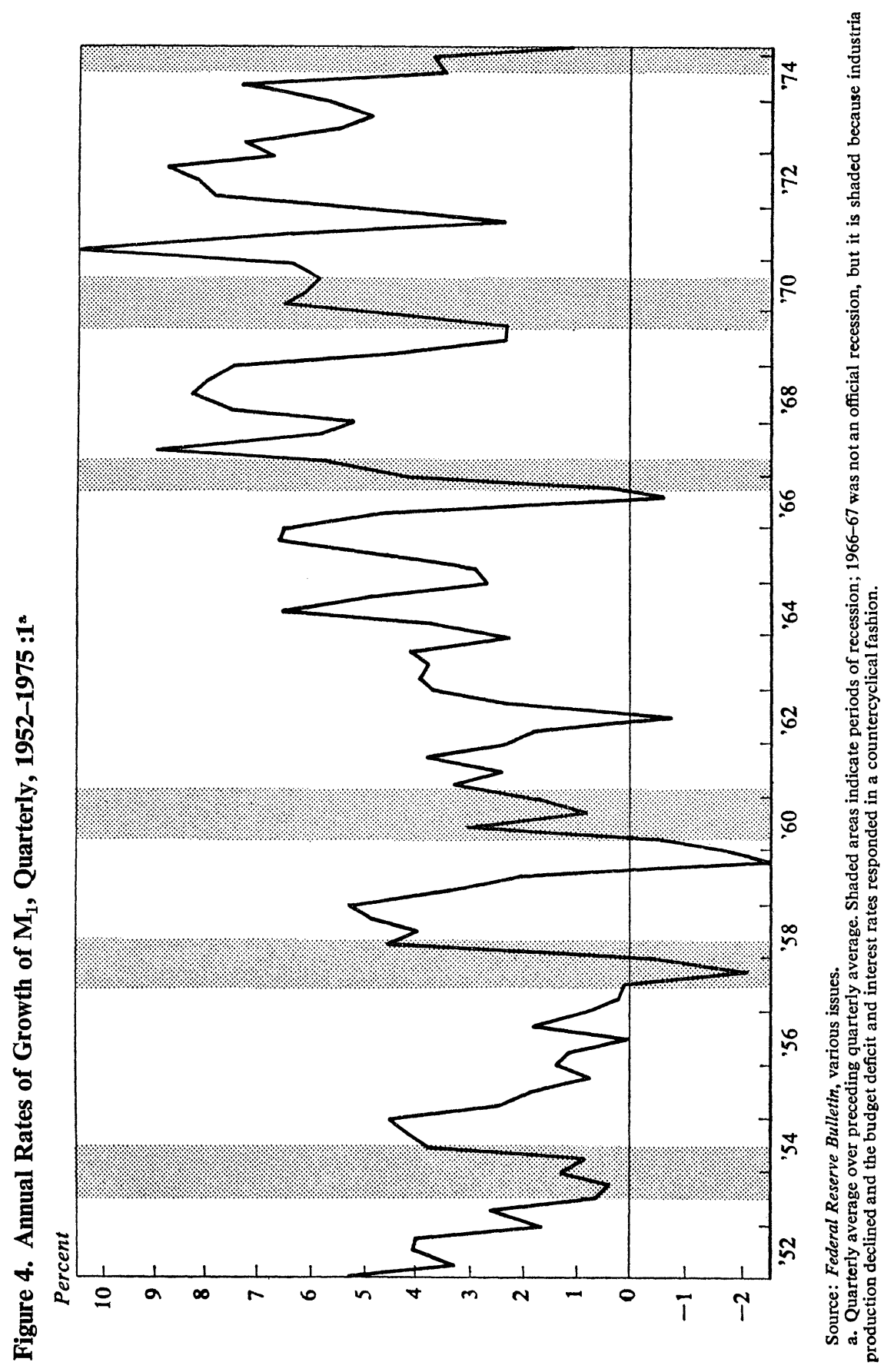


over the same 1952-1975:1 period. With the exception of 1958 and 1971-72, the most rapid $\mathrm{M}_{1}$ growth was associated with surpluses rather than deficits. This pattern illustrates a frequently procyclical behavior of $M_{1}$ growth rather than a financing of deficits through monetary expansion. Even in the case of the 1964 tax cut, interest rates drifted up gradually with economic activity; $M_{1}$ expanded in step with the economy until 1966.

This simple historical exercise is intended only to demonstrate that in the past deficits have not led to the kind of immediate interest-rate response that some observers seem to fear for 1975. There is no reason to believe that deficits resulting from recession-induced declines in tax revenues will spur increases in interest rates. Tax cuts and expenditure increases do tend to raise aggregate demand and, hence, ultimately to raise interest rates. But when this happens, the rise results from the autonomous increase in demand and not necessarily from an increase in the stock of outstanding debt. The question remains, however, whether a large increase in the stock of government debt associated with a deficit such as is now in prospect will be an additional factor raising interest rates even further and thus retarding the growth in private expenditures.

Unfortunately, conventional econometric models provide very little insight into the issue. They take no explicit account of the direct effects of the volume or composition of debt financing on financial markets. Through a series of identities, the models do provide estimates of the amount of debt raised by various sectors-government, business, and households. Identities are also used to equate the various forms of saving to aggregate investment. However, the volume of debt, as well as the demand for it, does not directly affect interest rates in these models. Short-term interest rates are determined by the interaction of money demand and money supply. Longterm rates are determined by term-structure equations that relate them to short rates. These interest rates influence total spending, which in turn feeds back on to money demand and hence again to interest rates in a simultaneously determined system. Thus, the basic determinant of interest rates is the growth of the money supply relative to current and lagged income, not the volume or relative supplies of debt. Tax cuts and expenditure increases therefore will raise income in these models, and the increase in aggregate demand will raise interest rates for any given money supply. The large prospective volume of government debt qua debt will have no impact. It is worth pointing out that these models have done a fairly good job of predicting interest rates without explicitly allowing for relative demands and supplies of credit. 


\section{The Outlook through Fiscal 1976}

As the foregoing discussion suggests, assessing the likely course of interest rates over the next year or so requires first some estimate of the course of aggregate demand and prices over that period. George Perry has kindly supplied me with his economic projection for 1975, and I have taken the liberty of extrapolating it through the first half of 1976 . While one may disagree with some features of this forecast, Perry's projections (and my extrapolations) are within the mainstream of current private forecasts. His projection has the added advantage of being very recent and of incorporating the actual tax program.

Perry does not assume significant "crowding out" of private expenditures in response to a deficit-induced rise in interest rates. Rather, he assumes that $M_{1}$ will grow fast enough to assure constant short-term interest rates as indexed by a $5 \frac{1}{2}$ percent Treasury bill rate over the forecast horizon. One test of the "surging interest rate" hypothesis will be to determine whether the Perry forecast is feasible given the prospective deficit and different assumptions concerning monetary policy.

\section{INTEREST RATES AND MONEY DEMAND}

The Perry GNP projection for 1975 and my extrapolations for the first half of 1976 are shown in table 1, along with data for 1974 for purposes of comparison. The annual percentage changes of GNP, GNP in constant dollars, and the implicit deflator for half years are shown in the following tabulation:

\section{Annual percentage change}

\begin{tabular}{ccc}
\hline Second half & First half & Second half \\
1974 to & 1975 to & 1975 to \\
first half & second half & first half \\
1975 & 1975 & 1976 \\
& & \\
0.25 & 12.3 & 10.4 \\
-8.1 & 6.9 & 5.2 \\
8.7 & 5.3 & 5.0
\end{tabular}

As the table shows, the projected expansion in nominal GNP is quite rapid. According to the money-demand function of the SMP model, this expansion would require an average growth in $M_{1}$ in excess of 9 percent to 


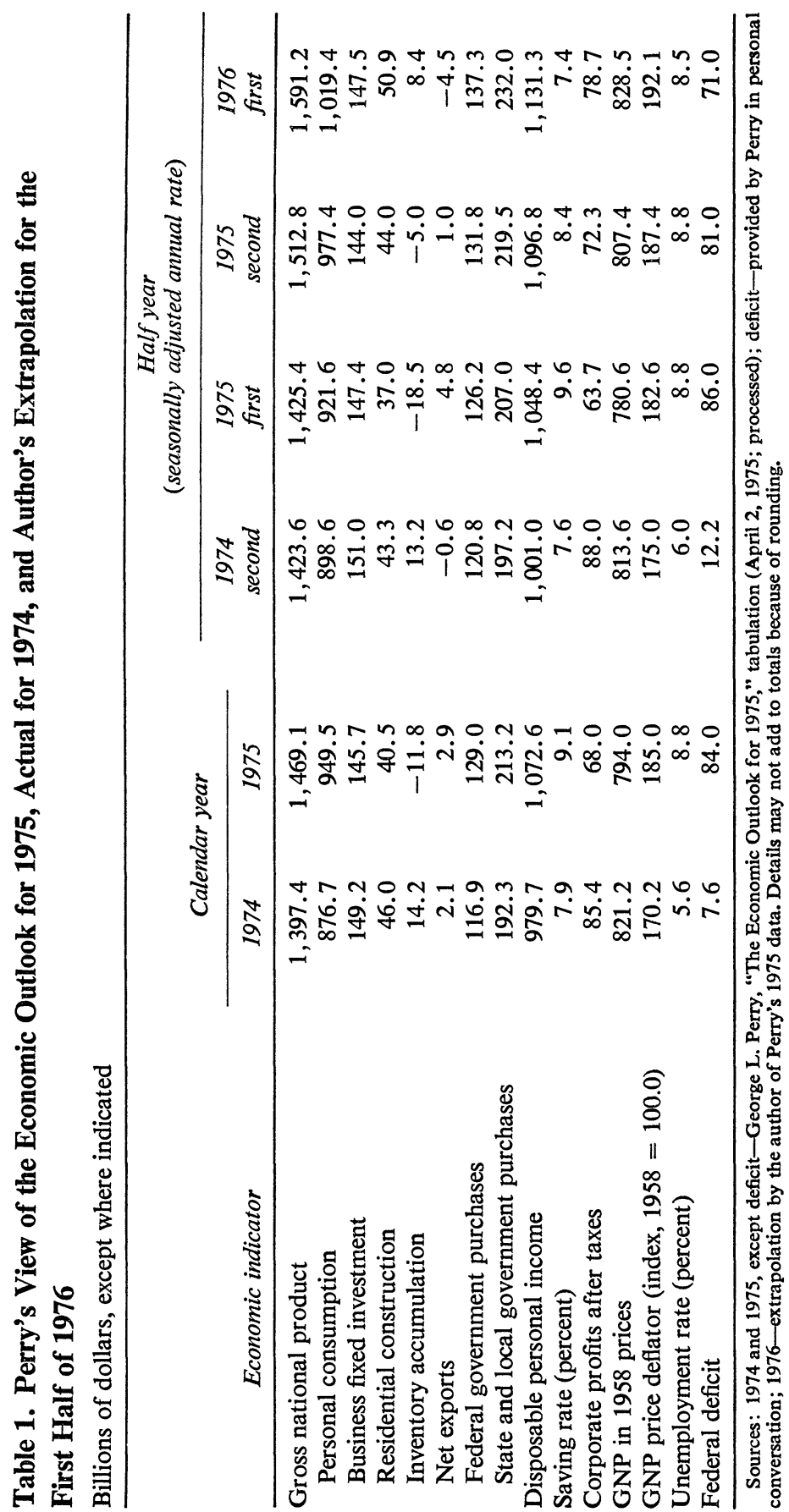


keep short-term interest rates constant through $1975 . .^{8}$ If the sharp rise in government debt puts pressure on interest rates beyond that measured by the money-demand equation, an even more rapid growth in $\mathrm{M}_{1}$ would be required.

Many observers would argue that Perry's implicit assumption about $\mathbf{M}_{1}$ growth is not realistic. It certainly does not accord with the 5 to 7.5 percent range recently announced by the Federal Reserve; ${ }^{9}$ interest rates would obviously rise with $\mathrm{M}_{1}$ growth in this range. Thus, Perry's GNP projection may be overly optimistic because rising interest rates induced by slow growth in $\mathrm{M}_{1}$ relative to GNP would dampen private spending.

To estimate the impact on Perry's projected GNP of such an incomeinduced rise in interest rates, the full SMP model was first adjusted to reproduce Perry's GNP forecast quarter by quarter, given constant interest rates. This simulation generated the $\mathrm{M}_{1}$ growth projection mentioned above. Then $M_{1}$ growth was set at 7 percent and a new simulation was obtained. Doing this reduced GNP by about $\$ 20$ billion by the fourth quarter of 1975 as a result of the slower expansion in $M_{1}$. The simulated Treasury bill rate stood at 6.50 percent in that quarter-a full 100 basis points above Perry's 5.50 percent assumption.

\section{THE DEFICIT}

The simulation just described demonstrates how much difference monetary policy can make working through conventionally modeled channels. The alternative projections for interest rates had nothing to do with the increased stock of government debt. The question still remains whether this rise in debt will be an additional force contributing to a rise in interest rates: Will the prospective new weight of the public sector in the mix of borrowing raise interest rates? Or, will the rate increases predicted by conventional econometric models capture the relationship between rising GNP and interest rates, given $M_{1}$ growth?

The present state of analytic knowledge gives a presumptive answer to this question. The efforts of model builders to find an explicit role for the

8. In this calculation the equation was adjusted for the large error in the fourth quarter of 1974.

9. See "Statement by Arthur F. Burns, Chairman, Board of Governors of the Federal Reserve System, before the Senate Committee on Banking, Housing and Urban Affairs" (May 1, 1975; processed). 
relative supplies of debt in the determination of interest rates indicate that once term-structure effects-which implicitly measure changes in the demand and supply of credit-are allowed for, no important role remains for changes in relative quantities of credit in the economy. ${ }^{10}$ Nonetheless, in view of the historic size of the government deficit, it is worth looking at as a special case.

Figure 5 displays the amount of U.S. government debt as a percentage of GNP from 1965 through the first half of 1976, the last three half-years representing the Perry forecast. The percentage rises sharply in the forecast period, but only back to 1969-71 levels, and it remains well below those for earlier years. Nothing in the behavior of this percentage suggests that the deficit for 1975 and 1976 will lead to unusually high levels of debt relative to GNP.

\section{FLOW OF FUNDS}

The next issue is whether the expected saving and investment flows are so unusual that financing the new debt of the government will be difficult and thus push rates higher. To examine the feasibility of Perry's forecast from this perspective required integrating government and private financing requirements with the Perry forecast. In a highly stylized exercise, I used an estimate of the flow of funds likely to be consistent with the Perry GNP forecast, assuming a sustained $5 \frac{1}{2}$ percent bill rate in 1975 and the first half of $1976 .{ }^{11}$ If the GNP pattern had implied "strains" in financial markets, in the form of unusually large shifts in the borrowing and lending propensities of the private sectors, perhaps the fears of extremely high interest rates would be justified or perhaps the GNP estimate would be too opti-

10. See, for example, Franco Modigliani and Richard Sutch, "Innovations in Interest Rate Policy," American Economic Review, vol. 56 (May 1966), pp. 178-97; and William D. Nordhaus and Henry C. Wallich, "Alternatives for Debt Management," in Issues in Federal Debt Management, Proceedings of a Conference Sponsored by the Federal Reserve Bank of Boston, June 1973 (FRBB, no date).

11. The flow-of-funds projection thought consistent with the assumptions about projected GNP and interest rates was kindly supplied by Stephen P. Taylor, of the Federal Reserve Board staff. $\mathrm{He}$ is in no way responsible, however, for the use to which I put his projection or for the conclusions that I draw from it. In this connection, it should be noted that flow-of-funds modeling is still an infant industry. Existing models are "rough" and analysis using them is somewhat unreliable. One of the newest and best analyses using the flow of funds for longer-term projections can be found in Barry Bosworth and James S. Duesenberry, "A Flow of Funds Model and Its Implications," in ibid. 
Figure 5. Ratio of the Stock of U.S. Government Debt to Gross National Product, 1965 through First Half 1976

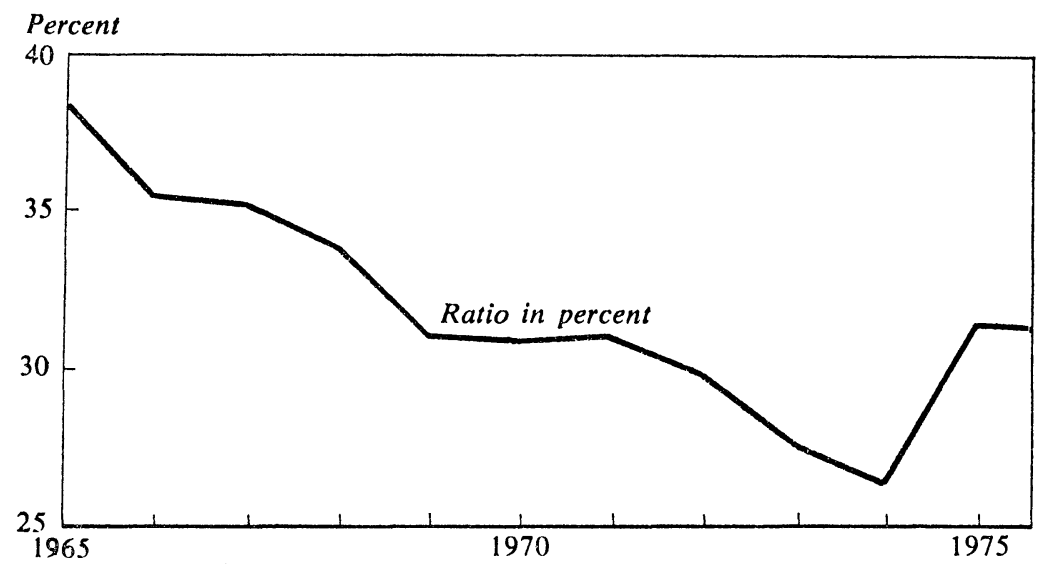

Sources: Board of Governors of the Federal Reserve System, "Flow of Funds Accounts, 1965-1973" (1974; processed), pp. 1. 31 ; table 1 above. Government debt for 1974 was obtained directly from Federal Reserve preliminary statistics; for $1975-76$ the debt figures are projections based on data for the preceding years.

mistic. If, on the other hand, there appeared to be no great difficulty in achieving the required mix in the flow of funds, the fears of surging interest rates would probably be without foundation, in the sense that monetary policy could produce Perry's projected path of constant short-term rates.

Table 2 shows the various components of gross saving and gross investment that Stephen Taylor has estimated to be consistent with the Perry forecast. While the identities require that saving equal investment, the manner in which the balance is struck is still instructive. The accounts are brought into balance in 1975 by a $\$ 45$ billion rise in private saving and a $\$ 35$ billion decline in private investment. The sum of these, $\$ 80$ billion, is sufficient to match the dissaving of the government sector.

The expansion in private saving comes from several sources. The tax cut and the general rise in personal income stimulates personal saving in 1975. Undistributed corporate profits will be down; but the saving from a reduced inventory valuation adjustment, which measures the rising replacement cost of inventories, actually raises business saving on balance in 1975 . The projected decline in investment is not the result of financial crowding out of projects-recall Perry's assumption of constant interest rates-but stems rather from high excess capacity. 
Table 2. Estimates of Gross Saving and Investment for 1975-76, and Actual for 1974, by Component

Billions of dollars

\begin{tabular}{|c|c|c|c|c|c|}
\hline \multirow[b]{2}{*}{ Component } & \multicolumn{2}{|c|}{ Calendar year } & \multicolumn{3}{|c|}{$\begin{array}{c}\text { Half year } \\
\text { (seasonally adjusted annual rate) }\end{array}$} \\
\hline & 1974 & 1975 & $\begin{array}{l}1975 \\
\text { first }\end{array}$ & $\begin{array}{l}1975 \\
\text { second }\end{array}$ & $\begin{array}{l}1976 \\
\text { first }\end{array}$ \\
\hline Gross private saving & 213.2 & 258.2 & 254.8 & 261.6 & 267.8 \\
\hline Personal saving & 76.7 & 105.4 & 109.4 & 101.4 & 94.1 \\
\hline Undistributed corporate profits & 52.5 & 33.2 & 29.6 & 36.8 & 42.3 \\
\hline Inventory valuation adjustment & -35.5 & -8.7 & -10.1 & -7.2 & -3.9 \\
\hline Capital consumption allowances & 119.5 & 128.3 & 126.0 & 130.6 & 135.4 \\
\hline U.S. government surplus & -7.6 & -83.6 & -86.2 & -81.0 & -71.4 \\
\hline State and local government surplus & 1.7 & -2.4 & -3.1 & -1.6 & -0.9 \\
\hline Total gross saving & 207.3 & 172.2 & 165.6 & 179.0 & 195.6 \\
\hline Gross domestic investment & 208.9 & 179.9 & 169.4 & 190.4 & 213.4 \\
\hline Net foreign investment and statistical discrepancy & -1.6 & -7.7 & -3.8 & -11.4 & -17.9 \\
\hline Total gross investment & 207.3 & 172.2 & 165.6 & 179.0 & 195.5 \\
\hline
\end{tabular}

Sources: 1974 data are from Board of Governors of the Federal Reserve System, "Flow of Funds, Seasonally Adjusted, 4th Quarter, 1974, Preliminary" (February 5, 1975; processed), p. 1. Other data are projections by Stephen P. Taylor of the Federal Reserve System, consistent with the Perry forecasts in table 1. For components calculable from table 1, the results may differ slightly because of data revisions and rounding. Details may not add to totals because of rounding.

The flow-of-funds projection shown in table 3 tells the story in a somewhat different way. Total funds raised by all nonfinancial sectors in 1975 are projected to be only $\$ 8$ billion higher than in 1974. The $\$ 80$ billion rise in U.S. government borrowing is almost totally offset by a $\$ 72$ billion $d e-$ cline in borrowings by other nonfinancial sectors. Funds raised by households and nonfinancial businesses are projected to decline by $\$ 23$ billion and $\$ 42$ billion, respectively. ${ }^{12}$ In light of Perry's projection of a $\$ 20$ billion rise in the rate of personal saving from 1974 to 1975, any source for strong upward pressure on interest rates from the household sector is hard to find. Given this increase in saving and the forecast weakness of housing demand, a sharp reduction is projected in the volume of funds raised on credit by households.

Table 4 shows the projection for 1975 and the first half of 1976 of gross investment and gross internal funds generated by the corporate sector, based on the Perry economy-wide forecast. Inventory investment declines sharply from 1974 levels and corporate fixed investment rises only moderately. Together, they imply a sluggish rise in gross investment, which re-

12. The recent large volume of long-term borrowing by nonfinancial businesses represents a restructuring of business balance sheets rather than a strong total business demand for funds. 
Table 3. Funds Raised in Credit Markets by Nonfinancial Sectors, 1972-76 Billions of dollars

\begin{tabular}{|c|c|c|c|c|c|c|c|}
\hline \multirow[b]{2}{*}{ Sector } & & & & & \multicolumn{3}{|c|}{$\begin{array}{c}\text { Halfyear } \\
\text { (seasonally adjusted annual } \\
\text { rate) }\end{array}$} \\
\hline & 1972 & 1973 & 1974 & 1975 & $\begin{array}{l}1975 \\
\text { first }\end{array}$ & $\begin{array}{c}1975 \\
\text { second }\end{array}$ & $\begin{array}{l}1976 \\
\text { first }\end{array}$ \\
\hline $\begin{array}{l}\text { Nonfinancial sectors, total } \\
\text { U.S. government } \\
\text { Other domestic, total } \\
\text { Households } \\
\text { Nonfinancial business } \\
\text { State and local government } \\
\text { Foreign }\end{array}$ & $\begin{array}{r}169.4 \\
17.3 \\
147.8 \\
63.1 \\
70.5 \\
14.2 \\
4.3\end{array}$ & $\begin{array}{r}187.4 \\
9.7 \\
170.1 \\
72.8 \\
85.1 \\
12.3 \\
7.5\end{array}$ & $\begin{array}{r}175.7 \\
13.0 \\
147.2 \\
42.5 \\
88.9 \\
15.8 \\
15.5\end{array}$ & $\begin{array}{r}184.0 \\
93.7 \\
84.8 \\
19.4 \\
47.2 \\
18.2 \\
5.5\end{array}$ & $\begin{array}{r}179.2 \\
97.1 \\
77.1 \\
14.5 \\
43.7 \\
18.9 \\
5.0\end{array}$ & $\begin{array}{r}188.9 \\
90.3 \\
92.5 \\
24.4 \\
50.7 \\
17.5 \\
6.1\end{array}$ & $\begin{array}{r}211.5 \\
74.5 \\
130.2 \\
49.5 \\
57.8 \\
22.9 \\
6.9\end{array}$ \\
\hline
\end{tabular}

Sources: Federal Reserve System, "Flow of Funds, Seasonally Adjusted, 4th Quarter, 1974, Preliminary," p. 2; and Taylor's projections, cited in table 2. Details may not add to totals because of rounding.

\section{Table 4. Gross Investment and Gross Internal Funds of Domestic Nonfinancial Corporate Business, by Component, 1974-76}

Billions of dollars, except where indicated

\begin{tabular}{|c|c|c|c|c|c|}
\hline \multirow[b]{3}{*}{ Component } & \multirow{2}{*}{\multicolumn{2}{|c|}{ Calendar year }} & \multicolumn{3}{|c|}{$\begin{array}{c}\text { Half year } \\
\text { (seasonally adfusted annual rate) }\end{array}$} \\
\hline & & & \multirow{2}{*}{$\begin{array}{l}1975 \\
\text { first }\end{array}$} & \multirow{2}{*}{$\begin{array}{c}1975 \\
\text { second }\end{array}$} & \multirow{2}{*}{$\begin{array}{l}1976 \\
\text { first }\end{array}$} \\
\hline & 1974 & 1975 & & & \\
\hline Gross investment, total & 125.8 & 106.4 & 100.4 & 112.4 & 128.7 \\
\hline Fixed investment & 115.7 & 116.2 & 114.4 & 118.0 & 123.1 \\
\hline Change in inventories & 10.1 & -9.8 & -14.0 & -5.6 & 5.6 \\
\hline Gross internal funds, total & 81.4 & 96.3 & 89.7 & 102.9 & 114.6 \\
\hline Undistributed profits & 34.6 & 18.7 & 14.3 & 23.0 & 28.0 \\
\hline Foreign profits & 9.8 & 7.4 & 8.2 & 6.5 & 6.5 \\
\hline Inventory valuation adjustment & -35.5 & -8.7 & -10.1 & -7.2 & -3.9 \\
\hline Capital consumption allowances & 72.5 & 78.9 & 77.3 & 80.6 & 84.0 \\
\hline \multirow{2}{*}{$\begin{array}{l}\text { Ratio of gross internal funds to } \\
\text { gross investment (percent) }\end{array}$} & & & & & \\
\hline & 64.7 & 90.5 & 89.7 & 91.5 & 89.0 \\
\hline
\end{tabular}

Sources: Federal Reserve System, "Flow of Funds, Seasonally Adjusted, 4th Quarter, 1974, Preliminary," pp. 1, 2; and Taylor's projections, cited in table 2. The calculations are made from data before rounding.

mains below the rate achieved in 1974 until the first half of 1976. Internally generated funds, on the other hand, are expected to rise because of a substantial reduction in the volume of funds required for inventory accumulation as a result of the slowing in inflation. This drop in IVA also serves to reduce taxes paid on inventory profits and therefore moderates the decline in undistributed profits. Thus, the corporate sector is expected to be a significantly smaller factor in capital markets than it was in 1974. Over the next eighteen months, the business sector should be able to finance most of its projected investment expenditures from internally generated funds. 
Figure 6. Funds Raised by the U.S. Government Sector as a Percentage of Total Funds Raised by Nonfinancial Sectors, 1952-76

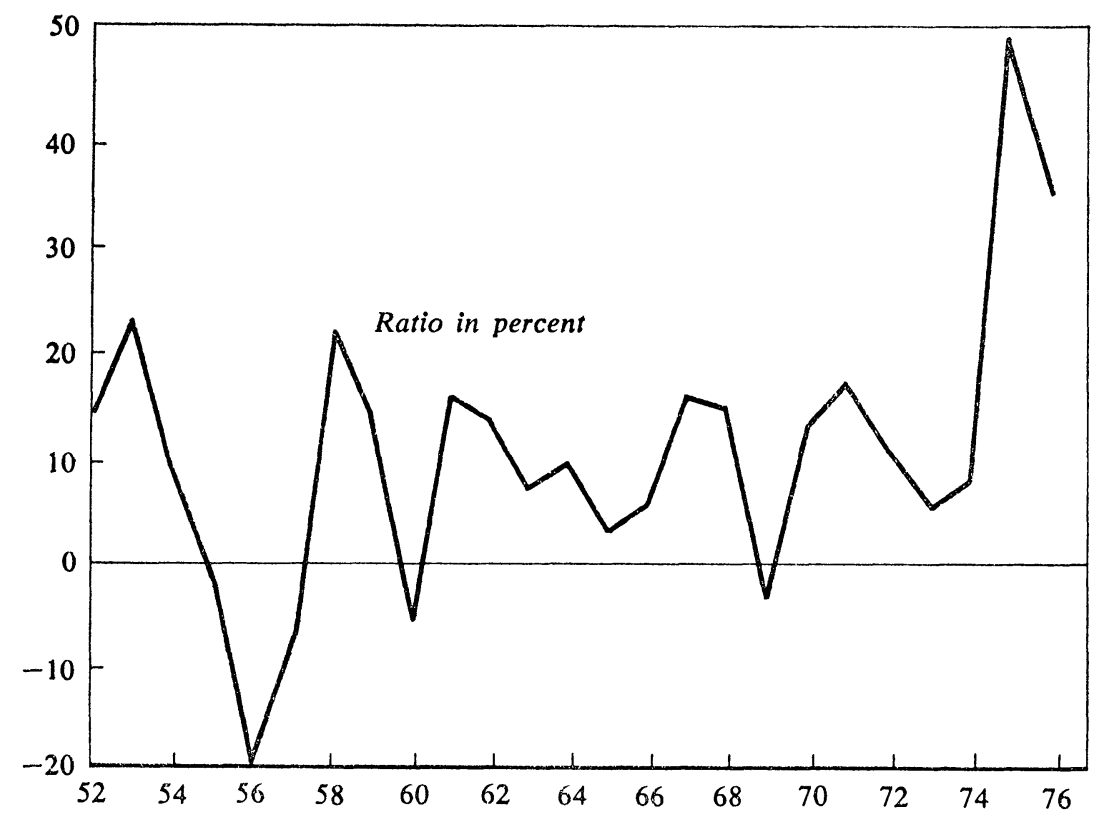

Sources: Federal Reserve System, "Flow of Funds Accounts, 1945-1972," pp. 4, 5; Federal Reserve System, “1974 Supplement: Flow of Funds Accounts, 1965-1973”'(September 1974; processed), p. 2; “Flow of Funds, Seasonally Adjusted, 4th Quarter, 1974, Preliminary," p. 2; and Taylor's projections, cited in table 2 .

\section{MARKET CONGESTION}

The evidence presented so far suggests that the fears over the interestrate implications of the large increase in federal debt are without foundation. The sharp increase in the saving rate combined with weak investment and housing demand should leave plenty of funds for the government to borrow. ${ }^{13}$ Another way to get at the issue is to look at the share of federal finance in total funds raised. Conceivably, if the federal share rises fast enough, financial markets will become congested and interest rates on government debt and substitute instruments will rise sharply. Figure 6 depicts a

13. This conclusion is similar to one reached independently by John Lintner, "Savings and Investment for Future Growth, 1975-76 and Beyond" (paper prepared for the Conference on Inflation and Recession, The Conference Board, New York City, April 8-9, 1975; processed). 
Figure 7. Share of U.S. Government Securities in Total Private Domestic Holdings of Credit-Market Debt, 1952-76

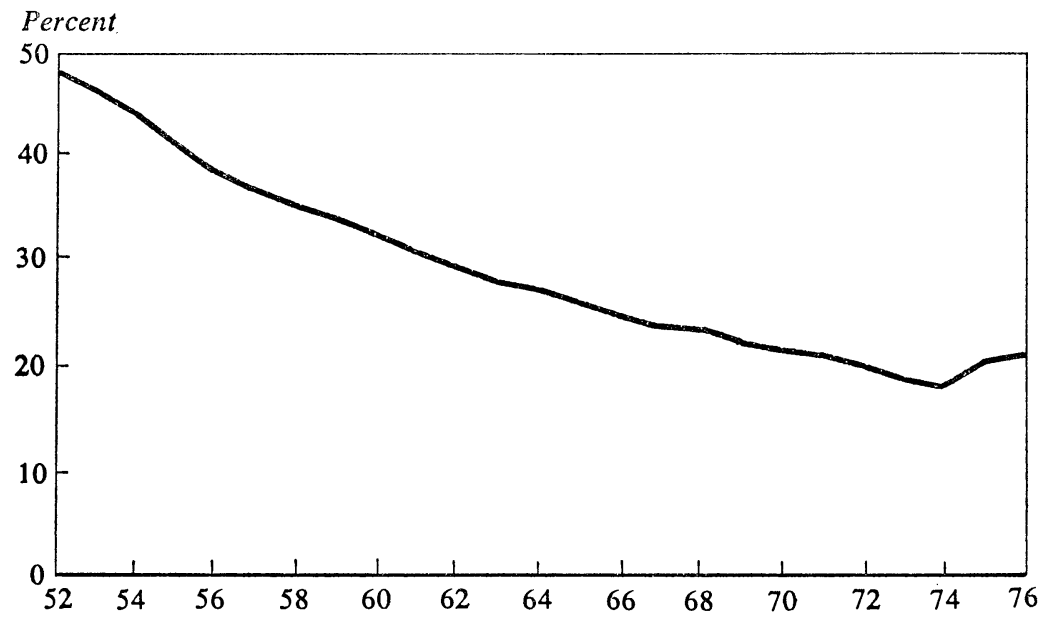

Sources: Same as figure 6 (pp. 78,27 , and 3 , respectively, of the published sources given).

time series of the ratio of federal debt to total nonfinancial funds raised. It clearly shows that, in 1975 and 1976, the government deficit will be large relative to the total borrowing needs of the nonfinancial sector as the U.S. government moves from its relatively minor role in financial markets to a major role-indeed, for a time, an unprecedented one.

While this shift in the weight of the public sector in the borrowing mix may disrupt financial markets-and one could already see signs in the early months of 1975 in the U.S. coupon market-it does not imply any dramatic shift in the composition of the public's portfolio of assets. Figure 7 shows that, while the share of U.S. government securities in total private domestic holdings of credit-market debt is expected to rise in 1975 and 1976, it will still be very low by postwar standards.

Although some congestion may develop in the government securities market from time to time, it cannot last long. Since the participants in this market have had ample time to prepare for the deluge of securities, the congestion is unlikely to be severe. While interest rates on government securities may rise somewhat relative to those on private issues, this change seems unlikely to push up the general level of interest rates.

The financial situation also offers no reason to doubt the feasibility of 
Perry's forecast-at least in broad outline. The flow of saving from the tax cut will directly and indirectly find its way into the government securities market and the economy should finance the deficit with little strain. The course of interest rates thus will depend, as usual, on monetary policy and not on the deficit. If monetary policy proves to be much more restrictive than Perry assumes, his forecast will be too bullish. This outcome would result from the conventional effects of monetary restriction and not from the large increase in government debt. 


\section{Comments and Discussion}

Stephen M. Goldfeld: In the first part of his paper, Pierce looks at the 1974 behavior of money markets, and an important part of this exercise is the relation between interest rates and money demand. In the second part, he looks at the likely course of interest rates during the next several quarters, and again the relation between interest rates and money demand is of central importance. However, what the past tells us about the future for this relation is left somewhat uncertain, and Pierce makes no special allowance for 1974's surprises in his projections. Pierce also discusses the extra impacts on interest rates that might arise from the large budget deficit that lies ahead, and finds little reason to expect any. So he ends up with a downthe-middle forecast that implies that interest rates will rise considerably if the Federal Reserve holds to a modest growth path for $\mathbf{M}_{1}$. I do not disagree with this assessment. But Pierce raises some provocative issues before reaching dead center and I would like to comment on some of these.

The basic puzzles in the first part of the paper are the large residuals in the third and fourth quarters of 1974 in the money-demand equation of the SMP model. As Pierce notes, these large residuals-in which actual money demand was $\$ 6$ billion and $\$ 11$ billion below predictions for the third and fourth quarters - in no way explain the slow growth of $M_{1}$ of this period. The Fed could have made money grow faster if it had wanted to-there was not even anything unusual in the relation between bank reserves and the money supply; but achieving this faster growth would have required pushing interest rates down much faster. Thus, the point of the exercise cannot be to explain the past growth of $\mathrm{M}_{1}$, but rather must be to understand the working of the demand function so as to help predict the $M_{1}$ requirements for the future. In this spirit, Pierce considers a number of reasons why money demand may have been unusually low. 
Before considering these, I can report the residuals from some alternative money-demand equations that I have run for this same period. The basic equation has a structure similar to the one presented by Pierce. The other two equations add the change in wealth and the inflation rate as explanatory variables. The residuals from these three equations, which were estimated with data through 1973, are presented below for the quarters since then:

\begin{tabular}{|c|c|c|c|c|c|c|}
\hline \multirow{2}{*}{ Equation } & \multicolumn{5}{|c|}{$\begin{array}{c}\text { Actual minus predicted } M_{1} \\
\text { (billions of dollars) }\end{array}$} & \multirow{2}{*}{$\begin{array}{c}\text { Five- } \\
\text { quarter } \\
\text { root } \\
\text { mean } \\
\text { square } \\
\text { error }\end{array}$} \\
\hline & 1974:1 & $1974: 2$ & $1974: 3$ & $1974: 4$ & $1975: 1$ & \\
\hline Basic & -2.5 & -0.4 & -4.5 & -6.7 & -1.2 & 3.8 \\
\hline With wealth & -1.5 & -0.9 & -4.0 & -5.5 & -1.5 & 3.2 \\
\hline With inflation & -0.9 & -0.1 & -3.1 & -4.5 & -0.8 & 2.5 \\
\hline
\end{tabular}

A few things are worth noting in these residuals. The basic equation has large errors, but not nearly as large as those that Pierce reports for the third and fourth quarters. The wealth and inflation variables reduce the residuals for these quarters somewhat further, indicating that they may belong in a specification of money demand. All the equations are nearly back on track by the first quarter of 1975, which suggests that whatever the mystery was in the second half of 1974, it has little importance for the future. This is also Pierce's conclusion. Finally, in connection with the second part of the paper, I also included the budget deficit in the basic equation and it did nothing, although this test has problems because the equation was in logs and the deficit had to be put in linearly.

I have a few comments on the explanations Pierce offers for the (perhaps) unusual behavior of money demand last year. First, the fact that a decline in real income gives a less than proportional decline in money demand need not imply unlearning in the sense that Pierce worries about. On a transactions view of the demand for money, the conventional model has people optimizing on money holdings and would predict the kind of result that Pierce describes. Unlearning or forgetting has nothing to do with this. To the extent that there is something else in the empirical results, it may be that real income is not the thing to look at. Perhaps innovations have in some sense produced shifts in money demand that conventional analysis has ignored. But interest rates might be a better candidate than real income 
for isolating any ratchet effects that come from innovation. Such effects could be part of the 1974 story even if they did not show up in previous recessions-simply because they are new phenomena. Or it might be that, whether real income or interest rates is the interesting variable, the changes are much steeper in the current situation than in past recessions. In either case, Pierce has raised a point that deserves further work.

Pierce looks at the savings flows to commercial banks and thrift institutions to see if $\mathrm{M}_{2}$ or $\mathrm{M}_{3}$ was better predicted than $\mathrm{M}_{1}$. Part of the problem in the poor predictive power that he reports for these equations may lie in the interest rate that is used. I think the SMP model uses a rate that has a $51 / 2$ percent ceiling, and if it does, the effect must be to understate both the height of effective rates and the variation in rates over past quarters.

When Pierce turns to projecting, he makes no special allowance for the residuals in the money-demand equations for 1974. His main message is that the fairly rapid growth in real and nominal GNP projected by Perry on the basis of a constant $5 \frac{1}{2}$ percent Treasury bill rate is unlikely to be consistent with a growth in the money supply anywhere near as slow as 6 percent. Indeed, the money supply would probably have to grow faster than 10 percent to conform to the Perry forecast. This relationship among the three variables-GNP, interest rates, and the money supply-gives Pierce his main handle for projecting interest rates for various scenarios. I would use the same handle.

Pierce also addresses the government deficit as an additional factor that might affect interest rates. Here his basic approach is to examine the flowof-funds analysis provided by Taylor on the basis of the Perry forecast. But there is probably such a big subjective element in the flow-of-funds breakdown that one could expect to find crowding out only if Taylor, in his judgment, included it.

To develop a satisfactory analysis from this kind of exercise, it would be useful to compare interest rates and the corresponding flows from Taylor with a complete constellation of interest rates from the GNP forecast and various assumptions about the money supply. One could then see whether those two sets of rates were roughly matched or badly mismatched. This is asking a lot from the present state of the art in flow-of-funds work, I know, and Pierce himself makes all the proper disclaimers about the state of that art. But if this work is ever going to convince people about something that they now do not fundamentally believe in, it will have to begin by undertaking analysis of this sort. 
David I. Fand: Pierce has written a very interesting paper, which takes up several important macroeconomic policy issues. The first part of the paper analyzes monetary developments last year and provides an understanding of the forces currently shaping money demand and interest rates. Pierce's analysis of the 1975-76 deficits in the second part offers a thoughtful assessment of the credit-market and interest-rate problems that the economy may face in the next twelve to eighteen months.

Pierce first considers the large decline in short-term rates, the smaller decline in long-term rates, and the sluggish growth in $\mathrm{M}_{1}$ in the third and fourth quarters of 1974. Using the money-demand function in the SMP model, he calculates that Treasury bill rates of 8.8 and 8.3 percent (in the third and fourth quarters, respectively) should have generated a 6 percent growth in $\mathrm{M}_{1}$ in the second half of 1974. The actual bill rates in these two quarters-8.2 and 7.4 percent, respectively-were below those calculated in the SMP model for 6 percent growth, yet $\mathrm{M}_{1}$ growth was only slightly above 2 percent over those two quarters. The question Pierce confronts is whether interest rates fell too much or money grew too little.

Pierce concludes that the sharp decline in short-term rates was not surprising, and that the moderate decline in long-term rates was not out of line with the term-structure equation in the model. Since movements in interest rates conformed to the model, the sizable 1974 errors in $M_{1}$ are viewed as the consequence of a downward shift in the money-demand equation. And since the model predicted the very rapid currency growth during the year quite accurately, Pierce associates the 1974 residuals for $\mathbf{M}_{1}$ with a downward shift in the demand-deposit function. While the 1974 residuals are large, it may be helpful to test whether they are large enough to reject the null hypothesis of no shift.

Several hypotheses, such as the "nonreversibility" of demand, changes in compensating balances, the use of a modified Treasury bill rate, and a shift from $\mathrm{M}_{1}$ to other monetary assets, are introduced to rationalize this shift in money demand, but those that help reduce the 1974 residuals do not work for earlier downturns. Pierce's ex post analysis of residuals cannot satisfactorily rationalize the assumed shift in money demand.

The strategy of associating the large residuals with a shift in the deposit function leads Pierce to a systematic analysis of the factors that could account for the change. And while this constructive approach does not as yet provide a satisfactory explanation, it may do better when the revised data are available. A less ambitious option would treat these large 1974 residuals 
as reflections of a temporary disequilibrium, following a large and precipitous decline in real income.

Although the recent behavior of money demand is viewed as something of a mystery, Pierce finds no evidence of a fundamental structural shift from $M_{1}$ toward savings and time deposits and nonbank intermediary claims. Indeed, the preliminary data for the first quarter of 1975 indicate smaller prediction errors. Pierce argues, therefore, that the Fed could have achieved a 6 percent growth in $M_{1}$ in the latter half of 1974 if it had supplied a larger volume of reserves.

Pierce's analysis of 1974 is that, in the collapsing economy of 1974, the interest-rate targets were not lowered fast enough to avoid sluggish money growth. A similar analysis of money demand and interest rates in a surging economy would indicate that interest-rate targets have not kept pace with money-market rates, and therefore accelerated, even explosive, monetary growth, may occur. One possible conclusion is that interest-rate targets are not the appropriate way to implement monetary policy, especially when the economy is undergoing transition.

Pierce's analysis of the prospective 1975-76 budget deficits reveals his considerable annoyance at the tenor of recent discussions. He is especially concerned over some widely publicized statements that foresee large deficits crowding out private investment expenditures and choking the prospective recovery, but that give no explicit analysis of the forces shaping aggregate demand in the next two years.

Pierce argues that there is no simple, direct, or automatic link between deficits and interest rates, and that the most rapid $\mathbf{M}_{1}$ growth was typically associated with surpluses rather than deficits (see his figure 3 on federal budget deficits and interest rates and figure 4 on annual rates of growth in $\mathrm{M}_{1}$ ). The historical record does not, in Pierce's view, support the notion that large deficits produce high or rising interest rates, nor does it support the associated fears that explosive money growth will inevitably follow the large 1975-76 deficits.

This approach, illustrated in figures 3 and 4, which compares contemporaneous deficits, interest rates, and rates of monetary growth is not, however, satisfactory. In assessing the impact of deficits on interest rates one should distinguish between Walter Heller's "passive" deficits and "active" deficits-that is, between an endogenous deficit reflecting weakness in the economy and a discretionary deficit reflecting a change in fiscal policy. Indeed, one would expect that the passive recession deficits will be asso- 
ciated with the low interest rates. Also, while an increase in the active deficits may, in time, cause interest rates to rise, this effect may not be detectable econometrically without allowance for lags. Even if deficits do not exert a major contemporaneous influence on interest rates, they could still have a significant net effect among the other factors affecting rates. Similarly, in the search for a statistical link between the active deficits and $M_{1}$ growth rates, the lagged effects of discretionary deficits on money growth should be investigated, as well as their initial influence on a broader monetary total such as $\mathbf{M}_{2}$.

Pierce's table 1, incorporating Perry's forecasts for real and nominal GNP and for the deflator, indicates a rise of over 11 percent in nominal GNP in the next twelve months. With the Fed's recently announced target of 5 to $71 / 2$ percent growth in $M_{1}$, the implicit speedup in velocity from the first half of 1975 to the first half of 1976 is between 3 and 6 percent, and supports Pierce's suggestion that the projected rise in GNP relative to the assumed growth in money would be associated with an increase in interest rates. This does not conform with Perry's forecast, which assumes a constant bill rate. In contrast, the flow-of-funds evidence in table 3 indicates that the $\$ 80$ billion rise in government borrowing in 1975 is offset by a $\$ 72$ billion decline in borrowing by other sectors, and suggests that the projected federal deficit can be financed without great pressure on interest rates. Pierce points out that the flow-of-funds methodology is still being developed, and I do not see that its implications for interest rates are as telling as those available from comparing the GNP estimates presented in table 1 with the Fed's monetary targets.

Pierce's discussion of the deficit and its impact on interest rates points up the need to define the alternative policies. For example, if a large budget deficit is essential to revive the economy within a given time frame, the deficit cannot validly be associated with any crowding-out effect; indeed, there is a filling-in effect. Alternatively, if a desired GNP path can be achieved without a deficit, or with a smaller deficit, then there is some kind of crowding out. Consequently, if the focus is on a given GNP path and if this path can be achieved with alternative policies incorporating larger or smaller deficits, the benefits and costs of these alternative policies should be considered. Determining whether a projected deficit-even a large one-will cause interest rates to rise and crowd out private investment expenditures is impossible without specifying the alternative policy. 
This policy issue is very similar to the one faced by the Kennedy administration's Council of Economic Advisers when it debated the merits of alternative methods of stimulating the economy in 1962. Some favored deficits to stimulate consumption and were willing to accept tighter money; others, seeking to stimulate economic growth, favored an easier monetary policy and were willing to accept tighter fiscal policy. In my opinion, discussion of the current problem would be improved if, like the 1962 debate, it focused more explicitly on the relative merits of alternative policies designed to achieve a given GNP path.

In spite of Pierce's excellent presentation, I am still puzzled as to the impact of deficits on inflation and interest rates. In the last decade, and especially since 1969 , the nation has had large deficits, high rates of monetary growth, high inflation, and high interest rates. One wonders whether some mechanism links these elements, or they just happened to move together in recent years. In my view, this conjuncture is not a happenstance. But if this interpretation of the inflation in the last decade is accepted, and if the 1975-76 deficits are not to ignite a new inflationary spiral, policy must assure that these deficits do not lead to an acceleration in money growth, and, indeed, that the economy returns reasonably soon to a noninflationary path for money growth.

\section{General Discussion}

A good deal of discussion centered on the relation between deficits and interest rates. William Fellner argued for analyzing the issue of crowding out private borrowing in the framework of policy alternatives. Low interest rates reflecting rapid money growth and large deficits reflecting tax cuts and spending increases represent alternative ways of achieving recovery. Choosing to stimulate the economy through a heavy reliance on deficits means higher interest rates than would otherwise occur. Hence, the composition of output will differ from that under the same stimulus with lower rates and a smaller deficit. Interest-sensitive demands, such as housing and business investment, will be lower with the large deficit than with the alternative policy. In turn, lower investment will result in less productivity growth. Robert Hall continued this line of thought, maintaining that, to the extent that contractionary monetary policy caused the recession, it was correct to em- 
phasize expansionary monetary policy to cure it. Because the extent of the diminution of the effect of fiscal policy through crowding out is unknown, it is difficult to know how expansionary fiscal policy should be.

James Tobin agreed that the crowding-out issue should be viewed in this framework of alternative policy mixes, as Fand had also suggested in his remarks. But he emphasized that in doing this, the path of GNP and employment had to be the same for each policy combination that was being considered. For a given path of GNP growth, substituting fiscal stimulus for monetary stimulus would produce higher interest rates and, in this sense, crowding out. But the public discussion about deficits was not being conducted in terms of an agreed-upon GNP path. The alternatives that were being argued were not all sufficient to do the same job of recovery. In particular, if fiscal policy were made less expansionary, achieving the same degree of recovery would require a faster growth of the money supply. Franco Modigliani argued that help from both monetary and fiscal policy was in order. The Pierce projections, as well as others that he had seen, indicated that even with the fiscal stimulus now in place, a very expansionary monetary policy would be needed to achieve anything like the 6 to 8 percent rate of real expansion that Perry was projecting. The issue arising from the Pierce paper was whether even this amount of monetary stimulus would be forthcoming. No one was contemplating the still faster growth in $\mathrm{M}_{1}$ that would be needed if the GNP expansion were to be fueled with monetary policy alone.

Marina Whitman believed that any discussion of crowding out had to take account of the international financial market. Not only would interest rates in the United States affect rates abroad, but there would be an influence in the other direction as well. If U.S. corporations have trouble raising funds in the U.S. market, they will borrow in the Eurodollar market or somewhere else abroad. And foreign and financial capital can be attracted to the U.S. market if interest rates are favorable or for any other reason, such as a changed assessment of the political climate or of the dollar's prospective value.

Lawrence Klein suggested that the simple correlation between deficits and interest rates in the historical record that Pierce presented was not sufficient evidence on the relation or lack of it between these two. He argued that it is the change of interest rates that one might expect to be related to the deficit, and reported that he had found a weak relationship using an equation that included other interest-rate determinants, such as free re- 
serves, along with the deficit. Klein also noted that the flow-of-funds analysis did show that big changes were coming in the sectoral composition of saving and investment balances, and suggested that such big changes in themselves might imply greater frictions in achieving the needed financial flows. Joseph Pechman pointed specifically to Pierce's projection that the ratio of federal debt to GNP would rise by 5 percentage points, while in previous recessions it had not risen at all noticeably. Pierce's analysis had not really addressed the issue of how this change would be smoothly accommodated. George Perry noted, however, that the real concern was for the course of private interest rates. To the extent that the government would have to borrow exceptionally large sums, the private sector as a whole would have to borrow exceptionally little. If some average of interest rates is maintained by monetary policy, this relative shift to government borrowing should cause a decline in private interest rates relative to the average. Tobin added that, on the same grounds, one would want to know whether an unusual change were taking place in the relative amounts of long- and short-term borrowing, since such a change would suggest a change in the term structure relative to its normal pattern.

Charles Schultze noted that, even if deficits and money demand (or interest rates) were not related historically, they might be in the coming months because a significant part of the deficit will come from the one-shot rebate of taxes. This rebate may temporarily expand money demand to the extent that households consider it a temporary increment to wealth that they plan to spend quickly. The money supply required to hold interest rates constant could be 2 percent higher when the rebate is first paid out. And this additional requirement-an 8 percent increment to the annual rate of growth for one quarter-would come on top of the rapid growth rates of money demand already projected by models such as Pierce's.

Several discussants commented on the 1974 errors in the money-demand equation that Pierce reported. Tobin noted that these equations assumed that money balances were in equilibrium. However, demand deposits should also be viewed as a sink for unintended differences between cash receipts and expenditures by individuals and businesses. A counterpart to disappointing sales and unintended accumulation of inventories would be disappointing receipts and an unintended fall in money balances. Pierce acknowledged the possibility, but noted that residuals like those of 1974 did not appear in previous recessions when, presumably, similar sales surprises and similar unintended inventory buildups occurred. Martin Feld- 
stein thought that the large spread between the commercial paper rate and Treasury bill rate would help to explain the spread of innovations such as money-market mutual funds in 1974 and thus the residuals in conventional money-demand equations. Arthur Okun replied that it was unlikely that movements into these assets came primarily at the expense of demand deposits.

Fellner expanded on the results reported by Stephen Goldfeld. He reasoned that inflation may have been an especially important factor in 1974 money markets. Historically, the inflation rate and interest rates may have moved together to such an extent that the inflation rate was not an important separable factor in the demand for money and other financial assets. But because of interest-rate regulations and the exceptionally high rate of inflation, rates could not track price increases as well this time.

William Poole found the interest-rate differentials between government and private debt a much more important feature of recent experience than the residuals in the money-demand equation for the last half of 1974. Money-demand equations are continually being revised and improved and residuals beyond the sample period are not uncommon. However, the huge gap that has opened up between the bill rate and private short-term interest rates has persisted for a long time and is more difficult to explain. Daniel Brill emphasized structural elements in bank balance sheets as an important reason for the wide discrepancy in rates. Banks were in a highly illiquid position, partly because so much of their capital was tied up in bad loans to real estate investment trusts. This situation helps explain why banks are so reluctant to make loans and why prime lending rates have remained so high relative to other money-market rates. On the view that business loans are the short-run dynamic factor causing changes in $\mathbf{M}_{1}$, this reluctance to make loans and the high bank lending rates that result from it make the Treasury bill rate a particularly inappropriate variable for explaining money demand at this time. The position of banks will also make it particularly hard for the Fed to generate an expansion in business loans. Despite these factors, Pierce commented that the relation between bank reserves and the money supply was not behaving in an unusual way. 